\title{
"GENTLEMEN, WHEN THE BARRAGE LIFTS" \\ A REVIEW OF NEW LITERATURE ON THE ORIGINS OF THE GREAT WAR
}

\author{
Christopher C. Lovett \\ Emporia State University
}

When the guns ceased firing, signaling the end of the Great War, it was not uncommon for bereaved loved ones or surviving comrades to post memoriam notes in British newspapers. Many such memorials were posted on July 1, 1917, the anniversary of the kick-off of the ill-fated British Somme offensive in 1916. One note that was repeated year after year in British papers was to the memory of those lost serving in the $9^{\text {th }}$ and $10^{\text {th }}$ Battalions of the King's Own Yorkshire Light Infantry. Shortly before the offensive began, officers of one of the battalions offered a toast and on the spur of the moment proposed, "Gentlemen, when the barrage lifts." The lifting of the barrage and the sound of a whistle were the signal for the infantry to go over the top and proceed across no-man's land. The initial assault engaged 800 men from those battalions. Within 24 hours, only eighty enlisted men and four officers had survived. All told, on the first day British losses included 20,000 killed and another 37,000 missing or wounded. ${ }^{1}$ No one inquired whether the veterans of that ill-advised operation, which lasted several months, knew what the conflict was all about or why it started.

In the years that followed the Great War, scholars of all stripes as well as combatants of all nationalities wrote about the conflict. Publishers provided the public with an assortment of books-memoirs, diplomatic histories, and combat narrativesabout the war, but few could understand why it had happened. A visit to the Combined Arms Research Library in Eisenhower Hall at Fort Leavenworth or any other major academic library in the United States or United Kingdom will introduce readers to the initial wave of publications available in their stacks. But this only raises questions concerning the significance of the Great War and its place in world history. Why should educators on all academic levels - higher education or secondary-spend valuable time in reviewing the Great War? Many of my students ask that question themselves, and, no doubt, many of yours do too. Many of the sources published following the Great War focused either on slanted diplomatic narratives or memorials to battles both lost and won.

\footnotetext{
'Paul Fussell, The Great War and Modern Memory (New York: Oxford University Press, 1974), 315316; Edward Rothstein, "Revisiting the Nightmares of World War I," New York Times, August 15, 2014, accessed August 16, 2014, http:/www.nytimes.com/2014/08/16/arts/design/first-world-war-galleriesreopen-at-imperial-war-museum-html? $\mathrm{r}=0$.
} 


\section{Reflections on a War-Filled Century}

Modris Eksteins in Rites of Spring: The Great War and the Birth of the Modern Age (Boston: Houghton Mifflin, 1989) ties the Great War to the general thrust of modernity that followed in the war's wake. Eksteins believed, much as William Butler Yeats did in 1916, "A terrible beauty is born," as a result of the conflict, when creativity and destruction changed places. The late Paul Fussell examined how a British Tommy viewed the conflict through the prism of the English literary tradition in his classic, The Great War and Modern Memory (New York: Oxford University Press, 1974). As Fussell demonstrated in reviewing their memoirs, British veterans were seared by their experience and were unable to shake the horrors that they endured, what we now call post-traumatic stress disorder. ${ }^{2}$ Unfortunately those soldiers and their stories often do not resonate with students today who have only witnessed a world shaped by the tragedy of $9 / 11$.

Unbeknownst to a younger generation is the fact that most of the issues in foreign affairs that have shaped their lives can be traced to a political murder in a small Balkan backwater on June 28, 1914. The policymakers in Vienna, Berlin, Paris, St. Petersburg, and London could not have envisioned the forces unleashed by Gavrilo Princip's assassination of Franz Ferdinand and his wife, Sophie. With the subsequent war and defeat of the Central Powers, not only did Europe change, but so did the rest of the world. The Allies - the British and French--plotted the division of the Middle East in 1916 and artificially created Syria, Iraq, Palestine, Transjordan, and Lebanon. Problems that are still unfolding today are evident in a perusal of the New York Times or other news sources in print or on line as well in witnessing the barbarism of ISIS warriors in northern Iraq. While the principal belligerents were focusing on finding ways to defeat each other, Turkish nationalists-the Young-Turks-were seeking to settle old scores with their Armenian subjects in 1915, often aided by their Kurdish allies. The term "genocide," while not coined until the early 1940s, was an apt description for what unfolded over the next 29 years, and on August 22, 1939, a few days before the start of another devastating European conflict, Adolf Hitler at his Berchtesgaden retreat told his assembled generals, "Who, after all, speaks today of the annihilation of the Armenians?"3

Not only did the First World War engender the Armenian genocide but also the coming of Hitler. The Third Reich grew out of anger and bitterness provoked by the

\footnotetext{
${ }^{2}$ The belligerents had considerable difficulties in comprehending the neuropsychiatric conditions that prolonged stress caused frontline troops. Initially, medical professionals termed this condition "NYD," not yet diagnosed, and later gave it the name "shell shock." For a brief description see John Ellis, EyeDeep in Hell (Baltimore: Johns Hopkins University Press, 1976), 116-117.
}

${ }^{3}$ Louis P. Lochner, What About Germany? (New York: Dodd, Mead, and Company, 1942), 2. 
Versailles Settlement. In time, German nationalists claimed that the German Army was not defeated on the field of battle, but instead was stabbed in the back by Socialists, pacifists, and Jews, whom German extremists termed the "November Criminals." The road to the Second World War was conceived from the ashes of the Great War, at least in the minds of right-wing Germans. It is difficult, if not outright impossible, to visualize the origins of World War II without Adolf Hitler, a German World War veteran who rose from obscurity to the pinnacle of power in a revived and re-militarized Germany.

Hitler himself claimed that the war was a defining moment in his life. However, Thomas Weber in Hitler's First War (New York: Oxford University Press, 2010) questions those assumptions. Germans willingly followed Hitler, not because he promised a new war-even his ardent followers could not visualize how destructive the next would be-but by how he effectively liberated Germany from the shackles of the "Diktat of Versailles." As Weber notes, Hitler's war experiences as a regimental runner shielded him from the horrors that so many others had confronted. Hitler hid his war record so successfully, according to Weber, that General Kurt von Schleicher claimed that Hitler's "tales" were a "fabrication." But accounts of "Hitler's treatment at Pasewalk" had no discernible impact on a German public already blinded by Hitler's promises of new visions of a thousand-year Third Reich. ${ }^{4}$

The First World War has cast a shadow throughout Europe and the United States for generations. David Reynolds, a professor of international history at Cambridge, examines the long-term consequences of the Great War in The Long Shadow: The Legacies of the Great War in the Twentieth Century (New York: W.W. Norton, 2014). For years, particularly during the 1970s and 1980s, scholars focused on what Reynolds terms "the cult of memory." Reynolds is correct when he argues that memory has been "pushed too far" when covering the conflict, particularly in obscuring the direct, material impacts of the war," including the political and military as well as the intellectual consequences of what followed in its wake. ${ }^{6}$ If only the war could have ended in 1916 by a negotiated settlement, something Lord Lansdowne, a former British Secretary, had proposed in November 1916, the hatreds engendered by the mass causalities might have been avoided.

\footnotetext{
${ }^{4}$ Thomas Weber, Hitler's First War (New York: Oxford University Press, 2010), 287. Pasewalk was a military hospital in eastern Germany where Hitler was treated as a patient following a gas attack in Flanders.

${ }^{5}$ In addition to Paul Fussell and Modris Eksteins, Jay Winter is another scholar who has examined memory in his book Sites of Memorv, Sites of Mourning: The Great War in European Cultural History (New York: Cambridge University Press, 1995).
}

${ }^{6}$ David Reynolds, The Long Shadow: The Legacies of the Great War in the Twentieth Century (New York: W.W. Norton, 2014), xx. 
The futile Somme Offensive, where the cream of "Kitchener's Army" was decimated, dramatized the futility of the conflict. American novelist F. Scott Fitzgerald recalled the battle in Tender Is the Night (1934), when Dick Driver, the central character, informs his companions during a tour of the Somme battlefield: "See that little stream, we could walk to it in two minutes. It took the British a whole month to walk it-a whole empire walking very slowly, dying in front and pushing forward from behind. And another empire walked very slowly backward a few inches a day, leaving the dead like a million bloody rags." "It was that reality that Reynolds believed shaped the continent, especially the political climate following the collapse of Germany and Austria which generated the political havoc in the interwar years and brought forward the later horrors of the Second World War and the Holocaust.

\section{Europe and the World on the Eve of the Great War}

Europeans of nearly all persuasions were oblivious to the war clouds that were about to engulf Europe in the summer of 1914, and even today scholars find no ready call for war on the part of the European public. Charles Emmerson, a senior fellow at the Royal Institute for International Affairs, reviewed the world climate of that time in his book, 1913: In Search of the World before the Great War. Emmerson does not seek to find explanations for the coming of the war. Instead, he seeks to put the political and social climate in historical perspective by examining a number of cities throughout Europe, North and South America, and Asia. What he discovered was how small the world was becoming because of the revolution in communications and travel. He also found that the middle and working classes were too busy getting on with their lives, or simply trying to survive, to comprehend or even notice the warning signs that were appearing in European capitals.

Michael S. Neiberg demonstrates in Dance of the Furies: Europe and the Outbreak of World War I (Cambridge, MA: Belknap/Harvard, 2011) that there was a political disconnect between the civilian and military leaders and the general public in regard to the issue of war and peace. He found that there was no massive public push for armed conflict, no inflamed nationalism before August 1914. Peter Englund, the author of Beauty and the Sorrow: An Intimate History of the First World War (New York: Knopf, 2011), follows the same path by reviewing 25 subjects living in the belligerent states throughout the war years. He realizes that the bellicosity comes not before hostilities, but after the first shots were fired and casualty reports appeared in the papers. Still, there were serious tensions within many of the powers on the eve of the Great War which could have altered the coming of the war itself.

Arno J. Mayer in Persistence of the Old Regime (New York: Pantheon, 1981) noted that the Dreyfus case still divided France, as did the Irish Home Rule issue in

${ }^{7}$ F. Scott Fitzgerald, Tender Is the Night (New York: Simon and Schuster, 1934, 2003), 56-57. 
England, where the British had magically avoided open hostility and a damaging mutiny in the British Army when Herbert Asquith and his Liberals tabled the issue of Home Rule for Ireland. ${ }^{8}$ In Germany the "social question" divided Imperial Germany between conservatives and socialists. Austria-Hungary confronted restive nationalities that threatened the monarchy. In Russia, Nicholas II faced the fear of another revolution like the one that followed Russia's defeat at the hands of Imperial Japan in 1905. Jack Beatty, in The Lost History of 1914: Reconsidering the Year the Great War Began (New York: Walker, 2012), reinforces Mayer's assumptions with the notable addition of looking at the situation between the United States and Mexico following the Mexican Revolution of 1912 and President Woodrow Wilson's quest for a new world order south of the border. Not all scholars, however, are willing to accept either Mayer or Beatty's analysis blindly.

For far too long, scholars have avoided Mexico when examining the political climate in the United States in the years immediately before the outbreak of the European conflict. There are a few sources that can fill in the historical record. The late Robert Quirk's study An Affair of Honor: Woodrow Wilson and the Occupation of Veracruz (New York: W.W. Norton, 1962) details Wilson's objectives in Mexico and remains as valuable today as it was when published initially. The late John S.D. Eisenhower provides an overview of the Mexican Revolution and its significance to the United States in his second volume on Mexican-American relations in Intervention! The United States and the Mexican Revolution, 1913-1917 (New York: W.W. Norton, 1993). When Pancho Villa crossed the border and attacked Columbus, New Mexico, in 1916, it paved the way for Wilson to take an activist role in Mexico's internal affairs. Ellen Welsome, an investigative journalist, chronicles the Pershing expedition in The General and the Jaguar: Pershing's Hunt for Pancho Villa (Boston: Little, Brown, 2006). Mexico remained a major concern for Washington, and indirectly played a crucial role in Wilson's decision for war in 1917 following the British release of the

\footnotetext{
${ }^{8}$ Alfred Dreyfus, a captain in the French Amy, was accused of providing Germany with critical intelligence while serving on the French General Staff. He was tried and convicted for treason in 1895 and sent to the infamous Devil's Island. Soon doubts arouse concerning his guilt, led first by Georges Picquart, the chief of French counterintelligence, and Émile Zola, one of France's greatest men of letters. His arrest and conviction contributed to a wave of Anti-Semitic fervor throughout France, dividing the French public between those who believed in Dreyfus's innocence (Dreyfusards), who sought to reopen the case, and those who believed in his guilt (Anti-Dreyfusards). For more information on the case, see the classic study by Nicholas Halasz, Captain Dreyfus: The Story of Mass Hysteria (New York: Simon and Schuster, 1968); Ruth Harris, Drevfus: Politics, Emotion, and the Scandal of the Century (New York: Metropolitan Books, 2010); Piers Paul Read, The Dreyfils Affair: The Scandal That Tore France in Two (New York: Bloomsbury, 2012); Louis Begley, Why the Drevfus Affair Matters (New Haven: Yale University Press, 2009); Pierre Bimbaum, The Anti-Semitic Moment: A Tour of France in 1898 (New York: Hill and Wang, 2003); and two recent novels, Kate Taylor, A Friend in Uniform (New York: Crown, 2010), and Robert Harris, An Officer and a Spy (New York: Alfred A. Knopf, 2014).
} 
infamous Zimmerman telegram, which shocked Wilson and enflamed the American public.

Any number of individual events - a civil war in Ireland, a revolution in Germany, civil unrest in France and Russia, the disintegration of the Austro-Hungarian Empire, or a Second Mexican-American War-might have altered what would happen in Europe in the summer of 1914. Still, the European public was oblivious to the unseen forces driving Europe to war. During and after the war, all the belligerents did their utmost to mask their own role in the coming of the conflict as well as point their collective finger at Germany and the Central Powers. Revisionist historians, from Sidney B. Fay to Fritz Fischer, sought to ascertain war guilt dispassionately, but Margaret MacMillan asks in The War That Ended Peace: The Road to 1914 (New York: Random House, 2013), "What did the decision-makers think they were doing?" Even Max Hastings, a noted British journalist and historian, recently told the New York Times that "Germany could have dominated Europe in 20 years economically if only it had not gone to war." The best historiographical presentation of who was responsible can be found in the concluding pages of Gordon Martel's The Month That Changed the World: July 1914 (New York: Oxford University Press, 2014).

Even though many current scholars have simply repackaged what earlier historians have already written, their modern interpretations and narratives have considerable weight today. Although nothing in history is inevitable, European leaders in the prewar period were marching unknowingly, often in lock-step, toward the abyss that engulfed Europe from 1914 through 1918. Margaret MacMillan recounts European diplomacy since the Franco-Prussian War of 1870-71, from the rise of competing and dueling alliances to an unwarranted, if not unjustified, arms race. How could European monarchies, particularly the Austrians and the Russians handle the rise of irredentist nationalism in the Balkans, especially the Serbs who were St. Petersburg's clients?

Christopher Clark, the author of The Sleepwalkers: How Europe Went to War in 1914 (New York: Harper, 2012), begins his account with the rise of Serbia, particularly the period following the June 11, 1903, coup and the ascension of Dragutin Dimitrijevic, a key plotter in the murder of King Alexandr and Queen Draga and organizer of the "Ujedinjenje ili Smrt," "Union or Death," commonly called "the Black Hand." Dimitrijevic was seriously wounded during the storming of the royal residence and barely survived. Later, in honor of his significant role in the plot, Dimitrijevic, whose nom de guerre was "Apis," "the Bee," was promoted to lieutenant colonel and assigned to the intelligence section of the Serbian General Staff. For Dimitrijevic and

\footnotetext{
${ }^{9}$ Margaret MacMillan, The War That Ended Peace: The Road to 1914 (New York: Random House, 2013), xxxv; Steven Erlanger, "The War to End All Wars? Hardly. But It Did Change Them Forever," New York Times, June 26, 2014, accessed June 28, 2014, http://www.nytimes.com/2014/06/27/world/ europe/world-war-I-brought-fundamental-changes-to-the-world.htlm.
} 
his compatriots the objective was to create a greater Serbia. The goals were obvious: First, target the remnants of the Ottoman Empire and, second, hasten the collapse of the Habsburgs. An explanation or understanding of the origins of the Great War, as Clark notes, are first found in the machinations occurring in coffee shops and apartments in Belgrade.

To learn how the Serbs exploited the weaknesses in the Dual Monarchy, readers should turn to Geoffrey Wawro's account of the difficulties Vienna confronted in facing Serbia in A Mad Catastrophe: The Outbreak of World War I and the Collapse of the Habsburg Empire (New York: Basic Books, 2014). Wawro, the Director of Military History at North Texas State, demonstrates that Austria was "essentially [a] feudal power whose crown lands with their dozen nationalities were botched together in the sixteenth century ... limped into the twentieth century under attack from its own peoples, who wanted federalism, home rule, or independence." ${ }^{\prime 10}$ Sean McMeekin, the author of July 1914: A Countdown to War (New York: Basic Books, 2013), contends that Franz Ferdinand, who was determined to reform the empire, posed a clear threat to Dimitrijevic's plans. Even more problematic for Serbian plotters, the heir apparent opposed the annexation of Bosnia and realized that the Bosnian Crisis of 1908 "had wounded Russian pride deeply."11 For Apis, the assassination of the Austrian heir apparent would further Serbia's long-term ambition of creating a greater Serbia, particularly at the expense of the Habsburg domains.

The assassination of Franz Ferdinand was told well by both Joachim Remak in Sarajevo (Vancouver: Criterion Books, 1959) and Vladimir Debijer, a Bosnian and a former partisan officer with Tito, as well as the official Tito biographer, who wrote what was for a time the best single-source account of the assassination in The Road to Sarajevo (New York: Simon and Schuster, 1966). Dedijer believed that in normal times, the murder "could not have provoked such momentous consequences."12 McMeekin assumes that Vienna could have argued that Belgrade was "harboring terrorists," using the same logic of the United States following 9/11, thus justifying military action. The notable difference between the Serbian government in 1914 and the Taliban in 2001 was that there was no boasting, quite the contrary, and there was

\footnotetext{
${ }^{10}$ Geoffrey Wawro, A Mad Catastrophe: The Outbreak of World War I and the Collapse of the Habsburg Empire (New York: Basic Books, 2014), xxi.

${ }^{11}$ Sean McMeekin, July 1914: Countdown to War (New York: Basic Books, 2013), 4.

${ }^{12}$ Vladimir Dedijer, The Road to Sarajevo (New York: Simon and Schuster, 1966), 445.
} 
a certain willingness to arrest some of the conspirators, but not the ever-dangerous Dimitrijevic, who was too closely linked to the Serbian government. ${ }^{13}$

It is precisely the interregnum between the assassination on June 28 and the beginning of the war that has captured the attention of the new wave of scholarship. McMeekin was the first with July 1914 in 2013, followed by T.J. Otte's July Crisis: The World's Descent in War, Summer 1914 (Cambridge: Cambridge University Press, 2014), and Gordon Martel's The Month That Changed the World: July 1914. Margaret MacMillan asked how European policymakers could have failed to avoid war in the summer of 1914. Otte agrees and places the blame not on one policymaker, but on all policymakers for the unfolding tragedy that engulfed Europe. The European public viewed the tragedy in Sarajevo as just another example of Serbian political violence, not much different from the murder of King Alexandr and Queen Draga in June 1903. Unfortunately the murder of the Hapsburg heir apparent was more serious than anyone realized - commoners and statesmen alike during that fateful interval between war and peace.

\section{Gavrilo Princip and Franz Ferdinand}

Few among the generation who would endure the unendurable in the trenches to the time of the Armistice could foresee the upheaval created by Gavrilo Princip when he fired two rounds from his Serbian-issued Browning automatic, killing Franz Ferdinand and his wife. Of course, the Serbian government could not admit their complicity in the murders, especially the links to Serbian military intelligence. Although earlier studies explain Princip's role, few authors sought to convey to contemporary readers Princip's motivation and passion. Tim Butcher, no doubt with the anniversary of the Great War in mind, wanted to follow Princip's footsteps from his small village in the Balkans to Belgrade and his infiltration with his seven accomplices into Bosnia-Herzegovina to Sarajevo. Butcher, in The Trigger: Hunting the Assassin Who Brought the World to War (New York: Grove Press, 2014), was influenced by the most recent bloodletting in the Balkans during the Bosnian War, which he covered in the 1990 s as a war correspondent for British dailies. In many respects Butcher's work is an updated epilogue to Rebecca West's classic Black Lamb and Gray Falcon (New York: Viking, 1943), making his study a historical monograph as well as a unique travelogue into the mysteries of the Balkans and the region's violent past. Butcher did something that few writers have accomplished before or since: He found Princip's family and original home in a remote Bosnian village and conveyed the loneliness and poverty to his readers.

\footnotetext{
${ }^{13}$ McMeekin, 391; for a far earlier account, see R.W. Seton-Watson's Sarajevo: A Study in the Origins of the Great War (London: Hutchinson \& Co., 1925).
} 
The question remains: How then did a bloody assassination turn into a devastating conflict that toppled three dynasties and brought forth the modern era? Historians have sought explanations into why European statesmen permitted this tragedy to unfold. During the war all the belligerents wrote "color books" to explain and exonerate their policy decisions and point fingers at likely culprits. But it remains mystifying even today to explain why a political murder in the Balkans contributed to the mass carnage that followed. David Fromkin, writing in Europe's Last Summer: Who Started the Great War in 1914? (New York: Knopf, 2004), believes that historians have missed the point. Fronkin stresses that historians have assumed for too long that Europe confronted a single war following Serbia's rejection of the Austrian ultimatum of July 24,1914 , when in all practicality there were two wars, the Austria-Serbian clash and Germany's preemptive strike against Russia and France.

Color-Coded Books with Justifications for War

\begin{tabular}{|c|c|c|}
\hline Country of Origin & Color & Publication Date \\
\hline Germany & White Book & August 1914 \\
\hline Great Britain & Blue Book & August 1914 \\
\hline Russia & Orange Book & September 1914 \\
\hline Belgium & Grey Book & October 1914 \\
\hline France & Yellow Book & November 1914 \\
\hline Austria-Hungary & Red Book & June 1915 \\
\hline
\end{tabular}

Source: Gordon Martel, The Month That Changed the World: July 1914 (New York: Oxford University Press, 2014), 402.

Much like Fritz Fischer, Fromkin believes that Germany, particularly the chief of the German General Staff, Helmuth von Moltke, anticipated that Germany was confronting an untenable situation of two unrelenting foes-France and Russia - and realized that Germany faced an existential threat vis-à-vis the Entente powers. Therefore, Germany needed to embark on a preemptive strike before, as military scholars would say, the correlation of forces would overwhelm Imperial Germany. The assassination provided the justification, according to Fromkin, for Germany to unleash her military might before France and Russia became even more of a threat to Germany's national security. In Fromkin's estimation, time was not on Germany's side. On the other hand, Emperor Franz Joseph, Field Marshal Conrad von Hotzendorf, and Foreign Minister Count Leopold von Berchtold, with the lukewarm support of the Hungarian Prime Minister Count Istvan Tisza, sought a localized conflict between Austria and Serbia. More problematic, no one sought to stop Berchtold's plan, which 
was designed "to crush Serbia without outside interference." Quickly the Austrians discovered "their German ally had been working at cross purposes."14 Vienna had expected Berlin to keep Russia at bay while the Austrians made short work of the Serbs. Instead Moltke told Conrad to concentrate Austrian forces not against Serbia but in Galicia along the Russian border. In Fromkin's assessment the blame for the catastrophe of 1914 was Germany's and Germany's alone.

\section{Pointing Fingers}

Otte, writing much later, took a different tact in looking at the failure to avoid the European-wide conflict that engulfed the Great Powers. Otte correctly notes that all the principal Powers failed to comprehend the profound implications of the assassination for European stability. According to Otte, both Poincaré, the French President, and Sazonov, the Tsarist Foreign Minister, regarded "clarity of intention' as the best means of ensuring that the two Germanic Powers disengaged" from seeking a military solution to the crisis. However, did that actually happen? Unfortunately, British ambiguity, which had worked earlier in the century, was "not sufficient to restrain either Berlin or Vienna or force moderation on St. Petersburg and Paris" in 1914. ${ }^{15}$

More problematic for Otte was the inability of the Powers to visualize the changing diplomatic landscape in the early twentieth century. Otte believes "the field of vision of the continental Powers had narrowed" and they did not realize that AustriaHungary had slipped from the ranks of the Great Powers to a "greater Regional Power," primarily focusing on the Balkans and the Serbian threat. Although for years historians had argued one of the principal causations for the conflict was the alliance system, Otte disagrees, highlighting that it was the quality of the statesmen in St. Petersburg, Vienna, Budapest, Berlin, Paris, and London, who failed to understand the consequences of supporting their allies. For the French, Paris was "driven by a perceived need to demonstrate to Russia that France, herself, was alliance worthy." While Britain was an alliance member, "her ties with France and Russia on account of the colonial and imperial arrangements with these two powers had grown more distant on the eve of Sarajevo," As a result, Otte feels, "Talk of the alliance "system" as one of the contributing factors to the war, is exaggerated." 16

\footnotetext{
${ }^{14}$ David Fromkin, Europe's Last Summer: Who Started the Great War in 1914 ? (New York: Knopf, 2004), 299.

${ }^{15}$ T.G. Otte, July Crisis: The World's Descent into War, Summer 1914 (Cambridge; Cambridge University Press, 2014), 508.

${ }^{16} \mathrm{Otte}, 509-510$
} 
Sean McMeekin in his earlier study, The Russian Origins of the First World War (Cambridge: Belknap/Harvard, 2011), believes Nicholas II's government successfully managed to avoid criticism for its part in the conflict. McMeekin relates that a powerful clique within Russian officialdom assumed, much like Germany, that Russia was encircled by hostile powers-Austria-Hungary, Germany, and the Ottoman Empire. St. Petersburg constantly feared a "Crimean coalition" that "was replaced, after 1878 , with dread of an even more bewildering 'Congress of Berlin syndrome,' wherein, despite Russia having for once fought a war against Turkey in which no eneny coalition had coalesced, diplomatic defeat had nevertheless been snatched from the jaws of victory on the battlefield." 17

McMeekin feels that most accounts looking at the July Crisis fail to review Russian Balkan policy from the Balkan Wars through the assassination in Sarajevo. McMeekin notes that the Russians were not only revising Plan 19, Russia's initial operational mobilization plan, but also preparing for an amphibious operation to seize the Straits. Russia, as well as the other Powers, long assumed that the Ottoman Empire was about to collapse and actively planned to use the Black Sea Fleet and Imperial Army from the Odessa Military District to achieve St. Petersburg's objective. After reviewing the sources, he stressed that Russia opposed Berlin's posting of Liman von Sander to command the Turkish garrisons along the Straits, as well as their opposition to Britain's selling two Dreadnoughts to the Turks, because these were significant obstacles to Russia's on-going plans for the Straits.

McMeekin also surmises that St. Petersburg was aghast as Nicholai Hartwig, Nicholas II's ambassador who mobilized the Balkan coalition against the Turks during the First Balkan War, now threatened Russia's prime objective, Constantinople, in 1912. While this was occurring, McMeekin believes, the Russians "sanctioned a 'trial mobilization' in Poland as the war broke in October. On November 22, 1912, Russia's war minister, Sukhomlinov, prepared orders for a full-on yet 'partial' mobilization of the military districts of Warsaw (that is Russian Poland, targeting Austrian Galicia), Kiev (Russian Ukraine, targeting same), and, intriguingly, Odessa (from which an amphibious operation in Constantinople might be launched)." McMeekin believes that the most fascinating aspect of this move was that it was "almost identical to the one that would be mooted in July 1914 ... for Russia to appear to mobilize 'against Austria alone,' so as not to alarm the Germans."18

From the available evidence, McMeekin realizes that earlier scholars, especially those writing shortly after the war, assumed that St. Petersburg was less complicit than Germany and Austria. Unfortunately Russia, he believes, bears more responsibility

\footnotetext{
${ }^{17}$ Sean McMeekin, The Russian Origins of the First World War (Cambridge: Belknap/Harvard, 2011), 23.

${ }^{18} \mathrm{Tbid}, 24$.
} 
than many have assumed. In both of his works, The Russian Origins of the First World War and July 1914, McMeekin points to the assassination itself, and after reviewing the ground-breaking work of Luigi Albertini, The Origins of the War of 1914, stresses that the surviving participants do link the Russian military attaché, General Viktor Artamonov, to "Apis." One Serbian officer recalled that Artamonov, who later claimed he was not in Belgrade at the time of the event, actually gave the Serbs the go-ahead for the murder. The Russian ambassador, Nikolai Hartwig, also claimed he was not in Belgrade at the time.

More problematic was the official meeting between Poincare and Viviani and Nicholas II and Sazonov. Records are missing that could explain Russian and French collaboration at the time of the issuance of Vienna's ultimatum. France, it appears from all the sources, was not willing to support Russian plans fully. Sazonov, in meeting with the military staff, told staff officers to plan for a partial Russian mobilization, which was conceivable according to Plan 19. Still Sazonov believed it was possible to conduct a partial mobilization against Austria, without threatening Germany, a move that was operationally impossible, because mobilization of the Warsaw Military District would threaten Germany as seen from Berlin. The Russians had hoped that they could conduct the mobilization in secret, something that was difficult for the Russians to implement.

The "Blank Check" to Austria by the German Chancellor, Bethmann Hollweg, and the Emperor, William II, clearly pointed to Germany's guilt in the war's causation. However, their action should be viewed in light of the full range of documentary materials supporting claims that both Berlin and Vienna were complicit in the conflict. For Berlin, speed was critical, but that was impossible because of the internal politics of the Dual Monarchy and Count Tisza's conditional support for Berchtold's plan for military action against Belgrade. From those events we know what followed: Russia supported Serbia, France did not abandon Russia, and London stood by both Russia and France, resulting in world war. McMeekin asserts that "was hardly the way Germany wanted the story to turn out." Bethmann Hollweg's failure was that, when he "called the bluff of the Entente Powers," much to his complete surprise, Serbia "did not blink." 19

\section{Mistakes, Misunderstandings, and Miscommunications}

During the anniversary summer of the Great War, the media made much of how the First World War began by both mistake and miscalculation and how a relatively little known event, an assassination in Sarajevo, could spark a conflict of horrific proportions never envisioned by European statesmen. Barbara Tuchman had foreshadowed this interpretation in her 1962 bestseller, The Guns of August, which

\footnotetext{
${ }^{19}$ Tbid., 45 .
} 
remained on the New York Times Bestseller List for 42 weeks. The central premise of her classic study was that the Great War was the result of policymakers making decisions without fully comprehending the potential consequences. ${ }^{20}$

The new sources concerning the July Crisis take a more nuanced approach to the outbreak of hostilities in 1914 than did Sidney B. Fay, Harry Elmer Barnes, Bernadotte Schmitt, Luigi Albertini, and Fritz Fischer, not because of access to more sources, but by the realization that all of the principal statesmen were directly or indirectly complicit in the tragedy following the assassination of Franz Ferdinand. All of the statesmenBerchtold, Bethmann Hollweg, Poincaré, Sazonov, and Grey-in one manner or another failed to visualize the consequences of a general war upon future European stability. They all permitted a single terrorist act, one which they normally would have condemned jointly, to cloud their judgment. Instead of seeking a Europe-wide response among the Powers, they sought geopolitical gain or the weakening of their perceived adversaries. The Great War did not have to happen. It was not ordained by earlier events, it was simply the failure of the best and brightest of the European aristocracy to realize that once wars begin it is nearly impossible to halt the carnage once the battle has been engaged, to the detriment of millions of men killed and the fate of the European dynastic system.

\footnotetext{
${ }^{20}$ John F. Kennedy read The Guns of August and was deeply "concerned with the unintended consequences of war after becoming commander in chief." According to Michael Dobbs, "the president was so impressed by the book that he often quoted from it, and insisted that his aides read it." If that was not enough, JFK wanted every military officer to read it too. Still, "unintended consequences" nearly came to pass. No single event following World War II came as close to general war than the 1962 Cuban Missile Crisis. Michael Dobbs, Minute to Midnight: Kennedy, Khrushchev, and Castro on the Brink of Nuclear War (New York: Vintage, 2008), 226.
} 